its unhappiness with the present structure of Intelsat. The report submitted by its Science Council in July last year, A Space Program for Canada, referred to the "peculiar status" of Comsat, the private company which is to build and operate the Intelsat system but which is also subject to United States domestic jurisdiction. "It appears unavoidable", the report declares, "that a conflict of interest will arise. Inherent in this arrangement is also a tendency on the part of other committee members to be especially sceptical regarding Comsat's ability to maintain an objective point of view on questions where political or economic interests of the United States are involved."

Whatever the Canadians' opinion of Comsat, there are several reasons why they wish to build their own satellite. A synohronous satellite offers considerable economies over conventional microwave networks for a country of Canada's size and spread of population. The spin-off from building the satellites-a field in which Canada has already established her prowess with the Alouette satellites-is likely to bring important benefits to many sectors of Canadian industry. A third consideration is the limited number of parking sites for geosynchronous satellites. Procedures for establishing rights of occupation have not yet been defined, but if the allocation of radio frequencies is any precedent the rule is likely to be first come first served. There are not more than seven satellite parking sites suitablo for Canadian domestic transmission and these are also of interest to other countries in North and South America. 'The Canadians wish to establish squatters' rights with their satellite as soon as possible.

\section{Chemists discuss Management}

\section{from a Correspondent}

The Chemical Society, Royal Institute of Chemistry, and the Institute of Chemistry of Ireland held a joint annual meeting in Dublin from April 1 to 6. During the meeting, a symposium on "Management in the Science Based Industries" was held, the first of its kind to be organized by the learned and professional societies. The innovation proved highly successful, if measured by attendance from the members of both societies and by the volume of active discussion promoted. Mr L. H. Williams (recently retired from Imperial Chemical Industries Ltd) and $\mathrm{Mr} \mathrm{H}$. $\mathrm{A}$. Collinson (Borden Chemical Co. Ltd) emphasized the differences displayed in science based industries, including rapid obsolescence of product and process, high capital investment and above average calibre of staff. Penalties for misjudgment could be heavy, right use of capital very important and demands on organization systems particularly exacting. Mr Collinson pointed out the dangers of the dogmatic use of rigid organizational methods in industries which must be constantly renewing their product lines and know-how.

The importance of financial control in large industry was dealt with by $\mathrm{Mr}$ P. T. Menzies (ICI), who emphasized the essential nature of a three to five year financial plan for proper allocation of resources-men, material and money. But he also warned the audience of the dangers of over-confidence-a rigid plan can rarely include everything, and depends on constant evaluation and correction by experienced and able management staff.

The special problems of the medium sized company were considered by Dr D. A. Harper (Storey Bros); good organization and planning were essential, as in larger companies, but more limited resources exerted constraints which had to be recognized. The important role of personnel managers was demonstrated by $\mathrm{Mr} \mathrm{J}$. Hartley (Shell Chemicals UK Ltd), who stressed that the objectives of the modern personnel function were to have the right people in the right jobs at the right time and to ensure that they were properly remunerated.

Research management in large organizations was exposed to some lucid analysis by $\mathrm{Dr}$ J. G. Collingwood (Unilever) and Dr D. S. Davies (ICI) Communications demanded some formal organizational structure, but Dr Davies was sure that this should be unobtrusive and aimed at encouragement of the individual and his liberation from intellectual constraints. This part of the symposium was effectively broadened by Sir Frank Warner's presentation of the proposed Anglesey aluminium smelter as a case study in his paper on the design and location of plant.

The last afternoon of the symposium was given over to a vigorous discussion on the relationships between university courses in chemistry and the needs of industry, introduced by Dr A. G. Sharpe (Cambridge) and Dr J. W. Barrett (Monsanto Chemicals Ltd) in two short papers entitled, respectively, "Criticisms of Industry" and "Criticisms of the Universities". These gave details of some of the findings of the comprehensive survey of the RIC, which is nearing completion. There seemed to be a healthy acceptance of many of the criticisms and these interim reports will be valued by many, as they are likely to be published many months before the full report.

\section{Computer Analysis of Salmon Migration}

A MODERN approach to the study of salmon migration has been started by a team led by Mr L. Stewart of the Lancashire River Authority and Professor W. E. Kershaw of the University of Salford. The project involves the use of a computer in a three year analysis of the factors involved in the migration of salmon to fresh-water rivers and those which might affect the fish on its return to the sea. The analysis appears to be the first of its kind in Europe and possibly in the world, and it is being helped by a grant of $£ 4,000$ from the Natural Environment Research Council.

Data from a number of rivers will be fed into the computer at intervals of about a month. Physical factors which may be connected with the movement of salmon are being recorded, particularly river flow, air and water temperature, amount of light, water level, turbidity, colour, silt, dissolved oxygen, conductivity, acidity of water, wind and speed direction, humidity, barometer pressure and solar radiation. The first sets of data are now being processed into readable form for a programme. To begin with, the project is being confined to one river - the Lune in Lancashire. Later, it is hoped to extend the analysis to the Kent, the Leven and possibly other rivers.

The information is being recorded electronically by a range of instruments installed at different places on the Lune and punched automatically into paper tape. In addition, special fish traps record all the fish swimming up or down the river. As the fish pass through an electric field, their movement is detected by instru- 
ments in the trap, the design of which has been in use since 1963 .

A considerable amount of data on physical factors which may affect salmon migration has been accumulated by the Lancashire River Authority, other fishery boards and university groups. It has been shown, for example, that more fish move upstream during the dark than in the daylight, and they also tond to move more when the air temperature is lower than the water temperature. Mr Stewart's department has also been getting interesting information on the mean water level in rivers necessary for migratory fish which apparently need deeper water than non-migratory fish. They have found, for example, that in the upper reaches of the Lune 26 miles from its mouth, and in the Leven only to0 yards from tidal waters, salmon require a very similar mean water level. In other words, the fish appear to need the same water level in estuaries and at the head waters of a river. It is obviously important to know the minimum water level tolerated by migratory fish, for then it can be judged how much water can be extracted from salmon rivers for urban and industrial purposes. The fishing value of the Lune is well over $£ 1$ million, so that more than just the pleasure of the local angler is at stake. The computer analysis is also expected to help in other directions. It may show, for example, how the number of fish in British rivers is being affected by netting salmon off Greenland.

\section{Fertile London Zoo}

$1 \times 1967$, for the third year running, attendances at the London Zoo exceeded two million. The council of the Zoological Society of London in its annual report attributes the high attendance to the attraction of the new buildings, to the general improvement of the exhibition and facilities for visitors and to an extensive advertising campaign and wide press publicity. At Thipsnade, the attendance of 588,825 was less than

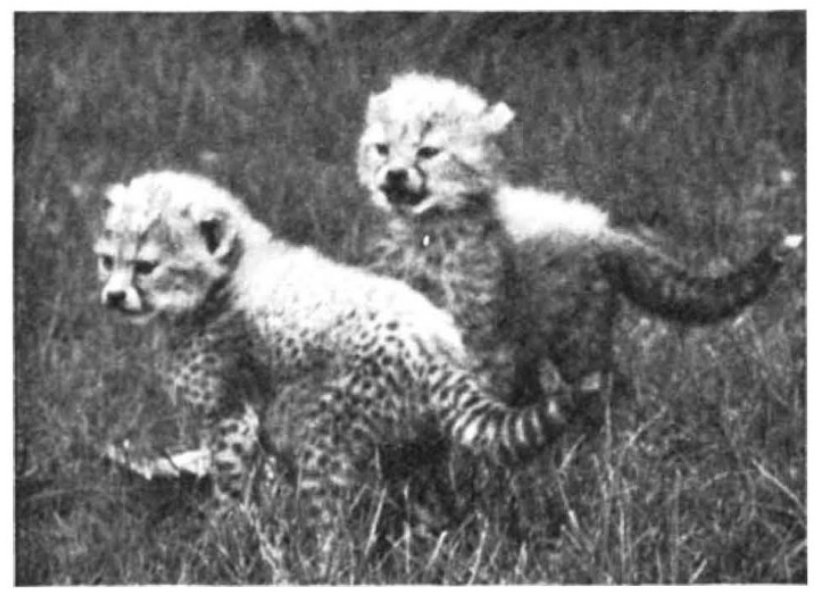

Two of the cheetah cubs born at Whipsnade in September.

in 1966, but the wet weather in May was probably partly responsible for the decrease.

Rebuilding at Regent's Park and improvements at Whipsnade continue to make heavy demands on the society's financial resources. Capital expenditure during the year was $£ 233,000$. The accounts for the vear show a small deficit, but the council has decided not to increase the entrance charges for 1968. The
Charles Clore Pavilion for mammals, opened last year, is said to have been a great success, but its popularity with visitors has brought some unforeseen difficulties, in particular the problems of noise and crowd control in the nocturnal section. Other works in progress are reported - the new combined sea-lion viewing stand and canine quarters building postponed from 1966 should be finished this summer.

The socicty is concerned to co-operate with other zoos in breeding projects. Its efforts on behalf of Chi-Chi, the giant panda, are well known. During 1967 its male snow leopard was sent to Amsterdam Zoo where there is a single female of this comparatively rare species. The chief breeding success of the year at Whipsnade was the birth in September of three cheetahs. The cubs, one male and two females, were left in their enclosure with their mother who has reared them entirely herself. This is the first time in Britain that cheetahs have been bred successfully and it is probably only the second time that cheetah cubs born in captivity have been reared by their mother.

Details are given of the society's scientific activities and research projects. The staff of the Nuffield Institute of Comparative Medicine now numbers 47. During the year the institute was designated by the World Health Organization as a collaborating centre for comparative pathology of non-domesticated vertebrates. Research at the institute included studies on viral and filarial disease in New World monkeys, trypanosomiasis, and nutrition in primates. Projects at the Wellcome Institute of Comparative Physiology included work on the reproductive cycle of the Skomer vole, problems of infertility in captive animals and reproduction in the chinchilla. The society's educational programme for schools seems also to have been a success - the number of pupils attending lecture. demonstrations increased by about 18 per cent over the figure for 1966. Membership of the Young Zoologists Club has also increased.

\section{Disease caused by Transfusion}

A RECEnT study undertaken by Allan G. Redeker and Carl E. Hopkins of the University of Southern California School of Medicine and the Los Angeles County Hospital has shown that whole pooled serum often transmits the virus causing hepatitis. Out of 120 patients studied over a period of three years, twelve contracted acute hepatitis within six months of receiving whole pooled serum, but not a single case occurred among patients receiving a control solution of five per cent serum albumin. The severity of this finding is further emphasized by the fact that the pooled serum in each case had been subjected to the method of sterilization normally used in the United Statesstorage for six months at room temperature followed by treatment with ultraviolet irradiation.

Pooling - the mixing of large quantities of plasma from the blood of many individuals-is used on a large scale in the United States, and it has been estimated that more than 300,000 units are administered annually. Serum is used primarily for severe burns and for transfusing to patients while they are waiting for their blood to be cross-matched. It was used extensively during the Second World War to revive and sustain the badly wounded. In view of 